\title{
AKSI KOLEKTIF DALAM GERAKAN PENOLAKAN AHLI FUNGSI LAHAN HUTAN OLEH PERUM PERHUTANI DI DESA SOLOKURO KABUPATEN LAMONGAN
}

\author{
Syifa'ul Qulub ${ }^{1}$, Aribowo ${ }^{2}$ \\ ${ }^{1}$ Departemen Politik, Fakultas Ilmu Sosial dan Ilmu Politik, Universitas Airlangga \\ syifaulqulub216@gmail.com \\ ${ }^{2}$ Departemen Politik, Fakultas Ilmu Sosial dan Ilmu Politik, Universitas Airlangga \\ aribowo@fisip.unair.ac.id
}

\begin{abstract}
This study focuses on the motives of community participation in collective action in the form of displacement over the function of forest land in Solokuro Village, Lamongan Regency. The researcher used a qualitative descriptive method with the aim to explore the findings. For the theoretical framework, the researcher chose Mancur Olson's collective action theory in exploring the phenomenon of collective movement. This theory explains the motives of individual participation in collection activities, supported by individual's interests. For communities who have lost their lands, they surely will be involved the collective actions with the hope that they will obtain the land permit back. For society in general, their participation in the movement was aimed to fight for the access of village road. The participation of community leaders and NGOs had purpose to obtain social incentives. Collective action conducted by the people of Solokuro Village succeeded in driving the developer out of the village forest land as a form of collective purposes and it can be seen when the community obtained the forest management permit back, namely Social Forestry Decree.
\end{abstract}

Keywords: Resistance Movement, Land Function Transfer, Collective Action.

\section{PENDAHULUAN}

Lahan hutan menjadi salah satu sumber daya potensial yang dimiliki oleh Indonesia. Dikutip dari laman resmi Kementerian Lingkungan Hidup dan Kehutanan RI pada September 2019, luas lahan hutan yang dimiliki Indonesia mencapai 93,95 juta hektar. Dengan modal sumber daya ini, seharusnya Indonesia mampu memenuhi kebutuhan pangannya sendiri. Faktanya, Indonesia masih sering melakukan aktivitas impor, dikutip dari portal berita CNBC Indonesia, mulai tahun 2000 hingga 2018 berturut-turut, Indonesia selalu melakukan impor beras. Hal ini menunjukkan bahwa Indonesia belum mampu memenuhi kebutuhan pangannya sendiri. Untuk mengatasi permasalahan tersebut, pemerintah memprioritaskan program kedaulatan pangan. Kabinet kerja yang dipimpin oleh Presiden Joko Widodo dan Wakilnya Jusuf Kalla, menargetkan swasembada pangan dalam kurun waktu tiga tahun. Untuk memenuhi target swasembada, pemerintah melalui Kementerian Lingkungan Hidup dan Kehutanan RI menerbitkan Peraturan Menteri Nomor P.81/MENLHK/SETJEN/KUM.1/10/2016 Tentang Kerjasama Penggunaan dan Pemanfaatan Kawasan Hutan untuk mendukung ketahanan pangan. Berdasarkan peraturan menteri tersebut, pemerintah melalui Kementerian Lingkungan Hidup dan Kehutanan RI dapat memberikan izin pengelolaan hutan kepada pengembang dengan tujuan untuk mendukung swasembada pangan.

Terbitnya Peraturan Menteri Nomor P.81/MENLHK/SETJEN/KUM.1/10/2016 memiliki dua tujuan utama. Selain untuk mendorong ketahanan pangan, peraturan ini juga bertujuan untuk mendorong 
partisipasi masyarakat terlibat dalam pengelolaan hutan. Dijelaskan pada Pasal 11 Huruf F, bahwa pengembang wajib melakukan kegiatan alih pengetahuan dan keterampilan kepada masyarakat sekitar hutan, dengan tujuan supaya dapat memudahkan masyarakat untuk terlibat dalam pengelolaan hutan. Kemudian pada Pasal 6 ayat 2, dipertegas bahwa pengembang wajib untuk melibatkan masyarakat sebagai mitra dalam mengelola hutan. Dilanjut dalam Pasal 8 ayat 2 yang mengatur mekanisme administrasi dalam proses pengajuan izin pengelolaan hutan, dalam poin ini dijelaskan bahwa salah satu prasyarat pengajuan izin adalah berupa proposal pelibatan masyarakat.

Implementasi menjadi faktor utama dalam melihat tingkat kesuksesan sebuah kebijakan. Terbitnya Peraturan Menteri Nomor P.81/MENLHK/SETJEN/KUM.1/10/2016 pada dasarnya memiliki tujuan yang bagus, yaitu untuk mendorong swasembada pangan serta partisipasi masyarakat dalam pengelolaan hutan. Namun, dalam implementasinya di Kabupaten Lamongan, kebijakan ini memberi dampak negatif bagi masyarakat sekitar hutan Desa Solokuro. Kehadiran PT. Wahyu Daya Mandiri menggeser masyarakat yang dulunya dapat secara leluasa mengelola lahan hutan. Keluarnya surat himbauan dari Perum Perhutani dengan Nomor 6/052.1/KJR/TBN/DIVREJATIM, menandai berakhirnya izin kelola lahan hutan oleh masyarakat. Surat himbauan tersebut berisi tentang instruksi kepada masyarakat yang mengelola lahan hutan untuk segera mengosongkan lahan garapannya. Berdasarkan pengakuan masyarakat Desa Solokuro, mereka belum pernah mendapat sosialisasi, baik dari pihak Perum Perhutani maupun PT. Wahyu Daya Mandiri terkait keterlibatan masyarakat dalam proyek lahan tebu. Dari sini peneliti dapat menarik kesimpulan bahwa PT. Wahyu Daya Mandiri telah melanggar peraturan yang menjadi dasar dikeluarkannya izin pengelolaan hutan. Hal ini karena peraturan tersebut mewajibkan pengembang untuk melakukan transfer ilmu serta melibatkan elemen masyarakat sebagai mitra dalam pengelolaan hutan. Terlepas dari pelanggaran yang dilakukan oleh PT. Wahyu Daya Mandiri, masyarakat melakukan gerakan kolektif karena merasa dirugikan.

\section{KERANGKA ANALISIS}

Pada penelitian ini, peneliti menggunakan metode kualitatif-deskriptif. Alasan peneliti memilih metode kualitatif-deskriptif karena metode ini memiliki kecenderungan untuk dapat melakukan eksplorasi secara detail terhadap fenomena yang dianggap menarik. Untuk teori, peneliti menggunakan teori aksi kolektif oleh Mancur Olson. Peneliti fokus melihat basis rasionalitas partisipasi individu dalam aktivitas kolektif. Individu yang rasional akan mementingkan dirinya sendiri, tidak akan bertindak untuk mencapai kepentingan bersama atau kelompok (Olson, 2002:2). Olson menjelaskan bahwa keterlibatan individu dalam aktivitas kolektif didorong oleh kepentingan pribadi. Kepentingan pribadi tersebut, dapat diupayakan melalui aktivitas kolektif. Olson mengembangkan pendekatan model teori utilitarian, pendekatan ini memandang setiap tindakan akan memiliki konsekuensi, pendekatan ini berusaha menjelaskan, dalam sebuah pengambilan keputusan harus melihat potensi keuntungan yang paling besar pada tingkatan individu. Lebih lanjut, Olson menjelaskan, untuk dapat memahami mengapa individu terlibat dalam suatu aktivitas kolektif harus dilihat melalui konsep biaya dan keuntungan (cost and 
benefits) (Olson, 2002: 21). Konsep ini berusaha melakukan akumulasi perbandingan antara biaya yang dikeluarkan dengan potensi keuntungan yang akan didapat oleh setiap aktor dalam gerakan.

Aktivitas kolektif dituntut untuk bisa menawarkan insentif. Insentif merupakan imbalan atau keuntungan yang didapat oleh individu yang terlibat dalam aktivitas kolektif. Olson membagi insentif dalam dua jenis, yaitu insentif ekonomi dan insentif sosial. Insentif ekonomi dapat berupa imbalan uang atau barang yang dapat diakumulasi secara materiil, sedangkan insentif sosial dapat berupa gengsi, rasa hormat, persahabatan, serta tujuan sosial dan psikologis lainnya (Olson, 2002:60). Olson menjelaskan tentang konsep barang publik (public goods). Barang publik merupakan barang yang dapat diakses oleh semua orang. Dalam proses penyediaan barang publik besar, potensi seseorang untuk menjadi penunggang bebas (free rider). Penunggang bebas merupakan individu yang tidak terlibat dalam upaya penyediaan barang publik namun dapat menikmati hasilnya (Olson, 2002:3). Untuk mengatasi masalah penunggang bebas, Olson menawarkan konsep insentif selektif. Insentif selektif merupakan insentif yang diberikan berdasarkan kontribusi individu dalam sebuah kegiatan kolektif. Insentif selektif dapat memberikan penghargaan kepada individu yang terlibat secara massif dalam aktivitas kolektif. Konsep insentif selektif penting untuk memfokuskan perhatian pada faktor-faktor selain tujuan kelompok yang memengaruhi keinginan orang untuk berpartisipasi dalam aktivitas kolektif (Olson, 2002:51). Olson berpendapat bahwa faktor determinan lahirnya suatu gerakan kolektif adalah tingkat homogenitas (Olson, 2002:23). Tingkat homogenitas bersumber dari basis identitas, isu, dan pengetahuan aktor dalam sebuah gerakan kolektif. Semakin homogen, basis massa dalam sebuah gerakan dapat mempermudah mobilisasi gerakan. Basis massa yang homogen berdampak keseragaman motif serta tujuan individu untuk terlibat dalam tindakan kolektif. Olson menjelaskan bahwa, keberhasilan dalam aktivitas kolektif dapat diukur dari seberapa banyak keuntungan yang didapat oleh setiap individu. Keuntungan dapat dihitung melalui total keuntungan yang didapat dari sebuah gerakan. Keuntungan ini kemudian dikurangi dengan biaya produksi atau ongkos dalam melakukan gerakan.

Peneliti mencoba merangkum beberapa penelitian yang menggunakan teori aksi kolektif. Namun, peneliti masih sangat jarang menemukan penelitian yang membahas topik gerakan sosial dengan menggunakan teori aksi kolektif Mancur Olson. Padahal, cara pandang Olsonian merupakan induk dari pendekatan mobilisasi sumber daya dalam menganalisa gerakan sosial. Banyak peneliti yang lebih suka menganalisa gerakan sosial dengan pendekatan mobilisasi sumber daya ala Klandermans, Zurcher, maupun Snow. Mereka lupa bahwa akar dari pendekatan mobilisasi sumber daya bersumber dari pemikiran Olson dalam tesisnya yang berjudul The Logic of Collectife Action. Terlepas teori ini mendapat banyak kecaman karena dianggap terlalu pragmatis dan menghilangkan faktor ideologis, namun peneliti melihat bahwa Olson hanya berusaha menjelaskan kejadian secara realistis. Alasan utama peneliti memilih teori aksi kolektif Mancur Olson sebagai alat analisis dalam melihat fenomena gerakan penolakan alih fungsi lahan hutan karena peneliti menganggap bahwa teori ini menjadi teori yang paling rasional dalam membaca keterlibatan individu dalam akvifitas kolektif. 
Penelitian sebelumnya dilakukan Hinggarwati, Wiloso, dan Sari (2015), meneliti tentang gerakan yang terjadi pada platform media sosial Twitter dengan mengangkat judul Cyber-Collective Action Netizen Melalui Media Sosial Twitter Hashtag \#SHAMEONYOUSBY. Gerakan ini dipicu dengan dikeluarkannya RUU Pilkada oleh Susilo Bambang Yudoyono, yang pada saat itu berkedudukan sebagai presiden. Dalam penelitian ini, peneliti menggunakan teori aksi kolektif oleh Mancur Olson untuk menganalisa gerakan siber kolektif. Dalam temuan datanya, peneliti lebih banyak menjelaskan proses mobilisasi gerakan, namun kurang menjelaskan faktor untung dan rugi yang diterima oleh setiap individu yang terlibat. Selain itu, unit analisis yang dipakai bersifat makro, yakni netizen. Hal ini tidak sesuai dengan teori aksi kolektif oleh Olson yang mana unit analisisnya adalah individu. Peneliti menempatkan RUU Pilkada sebagai public goods (barang publik) yang memiliki dampak signifikan terhadap kepentingan individu dalam aktivitas kolektif. Padahal, dalam perspektif Olson secara tegas dijelaskan bahwa individu yang rasional akan mementingkan dirinya sendiri, tidak akan bertindak untuk mencapai kepentingan bersama atau kelompok (Olson, 2002: 2). Dari kutipan tersebut dapat disimpulkan bahwa Olson melihat individu sebagai aktor yang pragmatis, sehingga kurang mempertimbangkan kepentingan kelompok. Keterlibatan individu dalam aktivitas kolektif dipandang sebagai metode aktor untuk dapat mencapai kepentingannya.

Tri Mujiastuti dan Hasrul Hanif (2015) meneliti aktivitas kolektif dengan subyek Komunitas Kinahrejo di Gunung Merapi. Penelitian ini fokus melihat proses perkembangan ekonomi kolektif pascaerupsi Merapi. Krisis ekonomi yang dialami masyarakat sekitar Gunung Merapi pascaerupsi tahun 2010, mendorong masyarakat untuk membentuk komunitas kolektif bernama Kinahrejo. Masyarakat banyak bergabung dalam komunitas tersebut dengan harapan akan mendapat ekonomi yang layak. Olson menjelaskan bahwa aktivitas kolektif dituntut untuk mampu menawarkan insentif. Insentif merupakan imbalan atau keuntungan yang didapat oleh individu yang terlibat dalam aktivitas kolektif. Olson membagi insentif dalam dua jenis, yaitu insentif ekonomi dan insentif sosial. Insentif ekonomi dapat berupa imbalan uang atau barang yang dapat diakumulasi secara materiil, sedangkan insentif sosial dapat berupa gengsi, rasa hormat, persahabatan, serta tujuan sosial dan psikologis lainnya (Olson, 2002: 60). Dalam penelitian tersebut, peneliti menjelaskan bahwa keterlibatan masyarakat didorong oleh kepentingan individu berupa harapan mendapat insentif ekonomi.

Rokhani (2018) meneliti tindakan kolektif pada aktivitas ekonomi. Fokus penelitian ini berusaha melihat motif keterlibatan individu dalam kelompok kolektif pengekspor kopi. Bergabungnya masyarakat dalam kelompok pengekspor kopi, dengan tujuan agar dapat menitipkan kopi produksi mereka untuk diekspor ke luar negeri. Dalam penelitian ini, peneliti hanya fokus membahas tentang insentif ekonomi yang didapat oleh setiap individu yang terlibat. Peneliti luput tidak menjelaskan terkait potensi insentif sosial yang akan didapat oleh setiap individu. Selain itu peneliti juga tidak menjelaskan letak barang publik (public goods) yang dijadikan alasan keterlibatan individu dalam kegiatan kolektif.

Penelitian ini berfungsi sebagai pelengkap dari penelitian sebelumnya. Berdasarkan temuan, peneliti banyak yang menggunakan teori aksi kolektif oleh Mancur Olson hanya sampai pada tahap 
pengutipan. Hal ini berdampak pada cara pandang peneliti dalam membaca teori tersebut. Dikhawatirkan ketika hanya membaca kutipan, dapat mengaburkan tujuan utama teori tersebut dalam melihat sebuah fenomena. Dari tiga sampel penelitian di atas, ketiganya belum mampu menjelaskan fenomena secara utuh. Masih banyak indikator teori yang terlewat maupun salah dalam penempatan. Pada penelitian pertama, peneliti bias dalam menjelaskan unit analisis dengan mengambil representasi netizen. Hal ini tentu salah karena unit analisis dalam teori milik Olson adalah individu. Selain itu peneliti juga gagal dalam menjelaskan insentif yang diterima oleh aktor dalam kegiatan kolektif. Pada penelitian kedua, peneliti luput dalam menjelaskan insentif sosial, serta potensi lahirnya penunggang gelap (free rider). Dalam penelitian ketiga, peneliti luput dalam menjelaskan letak barang publik (public goods) yang dijadikan alasan keterlibatan individu dalam kegiatan kolektif. Oleh karena itu, penelitian ini memiliki fungsi untuk melengkapi penelitian sebelumnya. Minimnya penelitian tentang gerakan sosial yang dilihat dari sudut pandang aksi kolektif Mancur Olson, mendorong peneliti untuk mengisi ruang kosong ini. Harapannya ke depan banyak peneliti meneruskan penelitian ini, supaya teori aksi kolektif oleh Mancur Olson dapat terus berkembang dalam menganalisa gerakan sosial.

\section{PEMBAHASAN}

\section{Faktor Pendorong Lahirnya Aktivitas Kolektif}

Lahirnya sebuah aktivitas kolektif, didukung oleh beragam faktor. Mancur Olson menjelaskan bahwa sebuah aktivitas kolektif dapat terjadi karena dorongan kepentingan individu yang ingin dicapai melalui aktivitas kolektif (Olson, 2002: 9). Dalam hal ini, akumulasi kepentingan kelompok yang diusung oleh masyarakat adalah untuk mengembalikan hak kelola lahan hutan. Olson juga menjelaskan bahwa, dalam setiap aktivitas kolektif dituntut untuk mampu menawarkan insentif atau keuntungan bagi setiap individu. Insentif memiliki fungsi utama untuk menarik partisipasi masyarakat dalam aktivitas kolektif (Olson, 2002: 60). Peneliti mencoba melakukan klasifikasi terhadap tigafaktor utama yang memiliki kesesuaian dengan teori aksi kolektif yang dipaparkan oleh Mancur Olson.

Pertama, menganggu eksistensi barang publik (public goods). Olson menjelaskan bahwa gerakan kolektif sering kali terjadi karena terdapat kepentingan individu, yang kemudian disalurkan melalui kelompok (Olson, 2002: 34). Kehadiran PT. Wahyu Daya Mandiri di lahan hutan Desa Solokuro, diduga akan mengganggu keberlangsungan barang publik (public goods). Dalam konteks ini, barang publik yang dimaksud adalah lahan hutan serta akses jalan desa. Dengan diterbitkannya surat edaran Nomor 6/052.1/Kjr/Tbn/DivreJatim dari Perum Perhutani, maka masyarakat tidak lagi dapat mengelola lahan hutan desa. Hal ini tentu sangat merugikan bagi masyarakat Desa Solokuro, lahan persawahan di Desa Solokuro tidak terlalu luas, sehingga masyarakat yang tidak memiliki lahan persawahan memilih untuk melakukan aktivitas pertanian lahan hutan. Banyak masyarakat yang dulunya berprofesi sebagai penggarap hutan kehilangan mata pencahariannya. Selain lahan hutan, kehadiran pengembang dikhawatirkan akan mengganggu kelancaran akses jalan desa. 
Kedua, dukungan dan upaya mendapat insentif sosial. Dukungan menjadi salah satu faktor penting lahirnya gerakan yang diinisiasi oleh petani Desa Solokuro. Dukungan datang dari berbagai pihak, antara lain Ali Mahfudz sebagai representasi tokoh masyarakat sekaligus anggota DPRD Kabupaten Lamongan. Pemerintah desa yang direpresentasikan oleh Kepala Desa Solokuro. Lembaga Masyarakat Desa Hutan sebagai representasi Lembaga Desa. Lamongan Watch sebagai representasi dari Lembaga Swadaya Masyarakat. Persaudaraan Mitra Tani Nelayan Indonesia (PETANI) Kabupaten Lamongan sebagai representasi organisasi petani. Dukungan datang berupa dukungan moril maupun dukungan materiil. Dukungan menjadi penting karena dukungan sebagai bentuk afirmasi bahwa aktivitas kolektif yang dilakukan masyarakat mendapat dukungan dari lingkungan sekitar. Hal ini dapat mendorong motivasi terhadap aktor dalam gerakan, supaya dapat konsisten dalam aktivitas kolektif. Penerimaan terhadap lingkungan sekitar menjadi penting. Hal ini terkait bagaimana masyarakat melihat gerakan tersebut. Jika dukungan datang dari banyak pihak, dapat ditarik kesimpulan bahwa aktivitas kolektif memberi dampak positif terhadap lingkungan.

Selain datang dari Lembaga Masyarakat Desa Hutan Wonosakti sebagai representasi masyarakat yang turut terdampak. Dukungan juga datang dari pihak yang tidak terdampak secara langsung. Olson menjelaskan bahwa setiap individu yang terlibat dalam tindakan kolektif akan mempertimbangkan insentif yang akan didapat (Olson, 2002:34). Insentif merupakan potensi imbalan yang akan diterima oleh individu dalam aktivitas kolektif. Bentuk insentif dibagi menjadi dua yakni, insentif ekonomi dan insentif sosial. Peneliti mencoba menjelaskan aktor yang tidak terkena dampak secara langsung. Menurut peneliti keterlibatan mereka dalam mendukung aktivitas kolektif, didorong oleh motif untuk mendapatkan insentif sosial berupa legitimasi dari masyarakat.

Ketiga, masyarakat yang homogen. Olson menjelaskan bahwa salah satu faktor penting yang mendorong lahirnya aktivitas kolektif adalah tingkat homogenitas basis individu dalam gerakan (Olson, 2002: 23). Tingkat homogenitas tidak hanya diukur dari total individu yang terlibat dalam aktifvtas kolektif. Namun lebih rinci tingkat homogenitas dapat bersumber dari basis identitas dan latar belakang pengetahuan. Basis massa yang homogen akan mempermudah proses mobilisasi gerakan. Hal ini karena, semakin homogen basis gerakan, maka motif dan tujuan yang diusung juga relatif seragam.

Mayoritas masyarakat Desa Solokuro memiliki profesi sebagai petani. Hal ini tentu dapat memudahkan proses konsolidasi dalam gerakan kolektif. Bertani tidak hanya sebagai profesi, namun lebih jauh sebagai basis identitas utama masyarakat dalam melakukan kegiatan sehari-hari. Basis pengetahuan sebagai petani, dapat mendorong solidaritas antar petani. Mereka paham bahwa dalam aktivitas pertanian, ketersediaan lahan menjadi sangat penting.

\section{Motif Keterlibatan Individu}

Olson menjelaskan bahwa untuk dapat melihat motif keterlibatan individu dalam aktivitas kolektif maka harus dipahami melalui konsep harga dan keuntungan (cost and benefits). Konsep ini menjadi pijakan, kelompok rasional dalam membaca aktivitas kolektif. Setiap individu yang terlibat dalam aktivitas kolektif, akan melakukan kalkulasi harga yang harus dikorbankan demi mendapat 
keuntungan yang lebih tinggi (Olson, 2002:24). Olson menyebut keuntungan dalam aktivitas kolektif sebagai insentif. Insentif dapat dibagi menjadi dua, yakni economic insentive (insentif ekonomi) dan social insentive (insentif sosial). Insentif ekonomi merupakan imbalan yang didapat dalam bentuk materi, seperti uang dan barang. Sedangkan insentif sosial merupakan imbalan berupa jabatan, ikatan pertemanan, serta hubungan sosial lainnya. Dalam subbab ini, peneliti akan melakukan kalkulasi dan pengelompokan harga serta potensi keuntungan yang akan didapat oleh setiap individu yang terlibat dalam aktivitas kolektif.

Olson menjelaskan bahwa dalam setiap aktivitas kolektif, akan mengeluarkan biaya. Biaya yang akan dikeluarkan harus memiliki nilai yang sebanding dengan potensi imbalan yang akan diterima oleh aktor dalam aktivitas kolektif. Dalam konteks gerakan di Desa Solokuro, masyarakat rela melakukan gotong royong dalam mengumpulkan sumber dana demi keberlangsungan gerakan. Masyarakat melakukan iuran secara sukarela, tergantung kemampuan masing-masing individu. Selain itu sumbangan juga datang dari tokoh masyarakat serta Lembaga Swadaya Masyarakat. Hal ini menandakan bahwa aktivitas kolektif yang dibangun oleh masyarakat berhasil membangun kesadaran. Kerelaan masyarakat dalam menyumbangkan sumber dayanya, didorong oleh harapan akan kembalinya izin kelola lahan.

Selain sumber daya materi, biaya juga dapat dikaitkan dengan bentuk pengorbanan yang dilakukan oleh individu. Seperti ketika mayoritas masyarakat Desa Solokuro berprofesi sebagai petani, sekaligus peternak rumahan. Hal ini mendorong masyarakat untuk jeli dalam membagi waktu dalam aktivitas kolektif. Siklus kegiatan warga Desa Solokuro biasanya dimulai sejak pagi menjelang subuh. Banyak warga yang berprofesi sebagai pencari daun jati di hutan untuk dimanfaatkan sebagai pembungkus bahan pangan di pasar. Setelah subuh, kegiatan dilanjut dengan aktivitas jual-beli di pasar. Memasuki pukul 07.00 WIB banyak warga yang mulai melakukan aktivitas pertanian, seperti bersihbersih rumput di sawah dan sebagainya. Aktivitas ini berlangsung hingga siang tiba, sekitar pukul 12.00 WIB. Pada siang hari, masyarakat menggunakan waktunya untuk istirahat, adapun beberapa melanjutkan aktivitasnya di sawah. Waktu sore dan malam menjadi peluang waktu yang dapat dioptimalkan untuk konsolidasi gerakan. Selama proses penolakan, masyarakat sering melakukan rapat untuk membahas perkembangan isu yang berkembang. Meskipun secara formal dan terencana hanya terlaksana dua kali, namun selebihnya masyarakat sering berkumpul secara insidental. Masyarakat juga silih berganti untuk menjaga posko gerakan yang bertempat di akses jalan masuk desa dan posko hutan. Hal ini untuk mengantisipasi kehadiran kendaraan besar milik PT. Wahyu Daya Mandiri.

Selain pertimbangan harga, terdapat pertimbangan keuntungan. Olson membagi keuntungan atau insentif ke dalam dua kategori, yakni economic insentive (insentif ekonomi) dan social insentive (insentif sosial). Insentif ekonomi merupakan keuntungan yang diterima oleh individu dalam bentuk materi. Sedangkan untuk insentif sosial dapat berupa kehormatan, jaringan, dan ikatan sosial. Insentif sosial memang sulit untuk dilakukan kalkulasi, karena ukurannya tidak dapat diukur secara materialistik. 
Meskipun begitu, insentif sosial tetap memberi ketertarikan bagi individu untuk terlibat dalam aktivitas kolektif. Hal ini karena insentif sosial dapat memberi manfaat dalam jangka waktu yang panjang.

Pada konteks aktivitas kolektif ini, potensi insentif ekonomi yang akan didapat oleh petani penggarap lahan adalah berupa izin pengelolaan lahan hutan. Dari izin tersebut, masayarakat dapat kembali melakukan aktivitas pertanian. Setelah kembali melakukan aktivitas pertanian, maka masyarakat dapat kembali menghasilkan uang. Hasil dari bertani tersebut dapat dikategorikan sebagai insentif ekonomi. Insentif sosial merupakan imbalan yang didapat secara tidak langsung, Dalam konteks aktivitas kolektif di Desa Solokuro, peneliti menemukan fakta bahwa insentif sosial tidak didapat oleh seluruh individu dalam gerakan. Insentif sosial hanya didapat oleh aktor yang memang memiliki motif tersebut. Berikut merupakan rangkuman peneliti berdasarkan hasil temuan di lapangan. Aktor yang mendapat insentif sosial antara lain, Ali Mahfudz. Selain berprofesi sebagai tokoh desa, beliau juga menjabat sebagai anggota legislatif sekaligus calon legislatif dalam pemilihan DPRD Kabupaten Lamongan. Peneliti melihat keterlibatan beliau dalam aktivitas kolektif didorong oleh harapan untuk mendapat dukungan dari masyarakat. Selain itu, kasus alih fungsi lahan di Desa Solokuro juga menjadi ajang bagi Ali Mahfudz untuk kembali memperkenalkan dirinya, melalui pernyataan media. Insentif sosial menjadi faktor penting sebagai modal untuk memperoleh simpati dari masyarakat. Kemudian ada Luqman Hakim sebagai kepala desa, beliau menjadi aktor kunci dalam keberlangsungan gerakan. Hal ini karena sikap yang diambil oleh kepala desa dapat memengaruhi cara pandang masyarakat atas sebuah fenomena. Kepala desa menngutamakan kepentingan masyarakat dari pada tawaran proyek perkebunan tebu. Hal ini melahirkan citra positif bagi kepala desa, citra tersebut dapat dikonversi menjadi insentif sosial berupa simpati yang lahir dari masyarakat. Amrozi, sebagai Ketua LMDH Wonosakti, beliau memiliki peran penting dalam proses konsolidasi gerakan. Beliau tidak banyak muncul di media, namun memiliki peran dalam berkomunikasi dengan berbagai mitra yang mendukung gerakan kolektif. Kontribusi tersebut dapat menghasilkan insentif sosial dalam bentuk kehormatan serta jaringan pertemanan. Terakhir, yakni Effendy Choirie, calon legislatif DPR RI Partai Nasdem Dapil X Jawa Timur. Beliau memanfaatkan akses jaringan partai untuk mendapat dukungan suara di Desa Solokuro. Diketahui bahwa Kementrian Lingkungan Hidup dan Kehutanan dijabat oleh Siti Nurbaya yang juga kader dari Partai Nasdem. Beliau mencoba menawarkan surat izin pengelolaan hutan kepada masyarakat yang kehilangan lahan garapan. Dengan terlibatnya beliau dalam aktivtas kolektif tersebut, beliau mengharapkan insentif sosial berupa simpati serta dukungan oleh masyarakat dalam proses pencalonan sebagai anggota legislatif.

\section{Penunggang Bebas (Free Ryder) dan Upaya Pencegahan}

Olson dalam pemaparannya menjelaskan bahwa aktivitas kolektif rentan dimanfaatkan oleh penunggang bebas (free ryder). Penunggang bebas (free ryder) merupakan individu yang tidak terlibat dalam upaya memperoleh barang publik ( public goods), namun dapat menikmati hasilnya (Olson, 2002: 76). Dalam konteks gerakan di Desa Solokuro, barang publik yang diupayakan berupa izin pengelolaan lahan hutan. Anggota LMDH memilliki potensi yang besar untuk menjadi penunggang bebas. Hal ini 
karena banyaknya partisipan dalam gerakan, sehingga dalam setiap gerakan masyarakat tidak dapat mengingat siapa saja yang aktif terlibat. Ketika gerakan sudah mendapatkan hasil yang diharapkan, maka masyarakat dapat kembali mengelola lahan hutan, baik mereka yang terlibat maupun tidak terlibat dalam gerakan. Masyarakat yang terlibat dalam upaya mendapatkan kembali public goods tidak dapat melarang masyarakat yang tidak terlibat. Hal ini karena prinsip kepemilikan barang publik dapat menjadi hak setiap individu.

Untuk mengatasi masalah penunggang bebas, Olson menggunakan istilah insentif selektif. Insentif ini diberikan berdasarkan kontribusi individu dalam aktivitas kolektif. Dalam melakukan gerakan, koordinator melakukan pendataan ulang kepada anggota LMDH yang akan mendapat izin pengelolaan lahan. Melalui pendataan ulang ini, koordinator dapat melakukan proses seleksi dalam pemberian izin kelola hutan. Individu yang terlibat secara massif akan mendapat insentif yang lebih tinggi dari pada individu yang tidak terlibat. Dengan konsep ini, maka akan menekan potensi adanya penunggang bebas.

\section{Hasil Gerakan}

Sebagaimana dijelaskan oleh Olson, bahwa dalam melihat keterlibatan individu dalam aktivitas kolektif dapat menggunakan konsep biaya dan keuntungan (cost and benefits). Konsep ini berusaha melakukan akumulasi antara biaya atau bisa disebut modal dengan potensi keuntungan yang akan didapat oleh individu dalam aktivitas kolektif. Lebih lanjut, Olson menjelaskan tentang indikator keberhasilan aktivitas kolektif. Aktivitas kolektif dapat dikatakan berhasil ketika akumulasi keuntungan yang didapat oleh aktor dalam aktivitas kolektif lebih tinggi dari pada biaya yang dikeluarkan (Olson, 2002: 24-25).

Setelah melakukan gerakan kolektif dalam kurun waktu kurang lebih satu tahun, masyarakat mulai mendapatkan hasilnya. Pertama, PT. Wahyu Daya Mandiri meninggalkan hutan Desa Solokuro. Terlepas dari izin yang dikantongi oleh PT. Wahyu Daya Mandiri masih berlaku hingga tahun 2020. Namun setelah mendapat tekanan dari banyak pihak, PT. Wahyu Daya Mandiri akhirnya memilih untuk meninggalkan lahan hutan Desa Solokuro. Dikhawatirkan jika proyek ini berlanjut, akan terjadi respon yang lebih besar dari masyarakat. Sehingga potensi kerugian yang dialami oleh PT. Wahyu Daya Mandiri juga akan semakin besar. Alasan lain yang mendorong PT. Wahyu Daya Mandiri untuk mundur dari hutan Desa Solokuro disebabkan karena lahan hutan di desa tersebut tidak sebanding dengan luas lahan yang dikelola oleh PT. Wahyu Daya Mandiri di daerah lain. Kedua, masyarakat mendapat Surat Keputusan Nomor SK.5923/MENLHK-PSKL/PKPS/PSL.0/6/2019 dari Kementerian Lingkungan Hidup dan Kehutanan RI. Surat Keputusan tersebut berisi perjanjian perhutanan sosial dengan menggunakan skema KULIN KK (Pengakuan Perlindungan Kemitraan Kehutanan) antara LMDH (Lembaga Masyarakat Desa Hutan) Wonosakti dengan KPH (Kesatuan Pemangku Hutan) Tuban. Diterbitkannya surat keputusan tersebut, menandai bahwa masyarakat dapat kembali mengelola lahan hutan secara legal. Namun, turunnya surat keputusan tersebut belum bisa membuat masyarakat merasa puas. Hal ini karena terbitnya Surat Keputusan tersebut, tidak kemudian menghapus izin pengelolaan 
hutan milik PT. Wahyu Daya Mandiri. Selain itu, skema KULIN KK bukanlah pilihan masyarakat, melainkan hasil dari intervensi pihak Perum Perhutani. Mulanya masyarakat mengajukan skema IPHPS (Izin Pemanfaatan Hutan Perhutanan Sosial), namun ternyata yang keluar adalah skema KULIN KK (Pengakuan Perlindungan Kemitraan Kehutanan). Kedua skema ini memiliki perbedaan yang cukup signifikan, dimana KULIN KK menempatkan petani sebagai mitra dari Perum Perhutani sehingga dalam mengelola lahan hutan, masyarakat harus melakukan izin terlebih dahulu kepada Perum Perhutani. Untuk IPHPS, petani dapat secara mandiri mengelola hutan tanpa keterlibatan Perum Perhutanni. Ketiga, masyarakat mendapat perhatian dari pemerintah pusat. Terbitnya Surat Keputusan Perhutanan Sosial, mendorong kepedulian pemerintah terhadap petani Desa Solokuro. Posisi masyarakat sebagai mitra Perum Perhutani menjadi kunci datangnya banyak bantuan berupa alat penunjang produksi pertanian seperti mesin pemipit jagung dan mesin penepung m ultifungsi.

Berdasarkan penjelasan di atas, peneliti mencoba melakukan akumulasi antara harga atau ongkos yang sudah dikeluarkan dengan keuntungan yang didapat oleh masing-masing individu. Masyarakat secara umum sudah mengeluarkan ongkos berupa uang dan makanan yang dibayar secara sukarela. Begitu juga dengan tokoh masyarakat, selain berkorban materi, mereka juga bekorban waktu serta pikiran. Jika dikalkulasikan dengan hasil gerakan di atas, maka aktivitas kolektif di Desa Solokuro dapat dikatakan berhasil. Berdasarkan pemaparan Olson, bahwa aktivitas kolektif dapat dikatakan berhasil ketika harga yang dikeluarkan lebih sedikit dari total hasil atau insentif yang diterima oleh setiap individu (Olson, 2002: 24).

\section{SIMPULAN}

Kehadiran pengembang di Desa Solokuro mendapat penolakan dari masyarakat. Hal ini karena pengembang dianggap mengganggu eksistensi barang publik (public goods). Dalam konteks ini, barang publik yang dimaksud adalah lahan hutan dan akses jalan desa. Lahan hutan yang dulunya dapat dikelola oleh masyarakat, akan dialihkan menjadi lahan tebu yang dikelola oleh pengembang. Selain itu, kehadiran pengembang dikhawatirkan akan mengganggu akses jalan desa. Hal ini tentu sangat merugikan masyarakat. Proses konsolidasi gerakan berlangsung cepat, karena masyarakat Desa Solokuro merupakan masyarakat yang homogen. Hal ini memudahkan proses konsolidasi kepentingan dalam gerakan kolektif. Gerakan ini berpotensi melahirkan penunggang bebas (free ryder). Dalam konteks ini, potensi penunggap gelap dapat dilakukan oleh dua kelompok. Pertama, anggota LMDH yang notabennya adalah penggarap lahan hutan. Kedua adalah masyarakat Desa Solokuro secara umum. Jika target gerakan dapat tercapai, siapa pun dapat menikmati hasil dari aktivitas kolektif tersebut. Tidak terkecuali bagi mereka yang terlibat dalam gerakan maupun tidak. Untuk mengatasi masalah penunggang bebas (free ryder), Olson menawarkan konsep insentif selektif. Dalam gerakan ini, koordinator gerakan berusaha menerapkan konsep ini dengan cara melakukan registrasi ulang anggota LMDH. Dengan dibukanya registrasi ulang, maka koordinator gerakan dapat menentukan siapa saja 
yang akan mendapatkan insentif berupa hak kelola lahan. Penilaian ini berdasarkan tingkat partisipasi individu dalam upaya mendapatkan barang publik.

Keterlibatan individu dalam gerakan ini didorong oleh kepentingan pribadi yang diupayakan melalui aktivitas kolektif. Penggarap lahan hutan terlibat dalam gerakan dengan tujuan supaya mereka dapat kembali melakukan aktivitas pertanian di lahan hutan. Masyarakat Desa Solokuro secara umum terlibat karena ingin mempertahankan akses jalan desa, supaya mereka tetap dapat melakukan aktivitas di jalan desa. Ali Mahfudz sebagai anggota sekaligus calon DPRD Kabupaten Lamongan, tentu membutuhkan simpati serta dukungan dari masyarakat Desa Solokuro untuk memenangkan kontestasi kursi legislatif. Effendy Choirie sebagai calon legislatif DPR RI Dapil Jawa Timur X yang meliputi Kabupaten Lamongan dan Gresik, juga membutuhkan dukungan berupa suara dalam Pemilu. Kecamatan Solokuro termasuk dalam wilayah Kabupaten Lamongan. Hal ini yang menarik keterlibatan Effendy Choirie dan Partai Nasdem (Nasional Demokrat) dalam polemik alih fungsi lahan di Desa Solokuro.

Setelah melalui proses panjang dalam melakukan gerakan, masyarakat Desa Solokuro akhirnya mendapatkan beberapa hasil. Pertama, PT. Wahyu Daya Mandiri tidak akan kembali menanam tebu lagi di lahan hutan Desa Solokuro. Kedua, masyarakat mendapat izin pengelolaan hutan secara legal melalui SK Perhutanan Sosial dari KLHK. Meski sudah terbit SK Perhutanan Sosial, tapi masyarakat masih belum leluasa untuk mengelola lahan hutan. Hal ini karena SK Perhutanan Sosial yang diterima masyarakat dengan skema Kulin KK, sedangkan yang diharapkan masyarakat adalah skema IPHPS. Kedua skema ini memiliki perbedaan yang signifikan. Skema Kulin KK menempatkan masyarakat sebagai mitra dalam mengelola hutan, namun fakta dilapangan masyarakat tidak dilibatkan dalam proses perencanaan oleh Perum Perhutani. Ketiga, terlepas dari permasalahan skema SK Perhutanan Sosial, masyarakat mulai sering mendapat perhatian dari pemerintah. Mulai dari mendapat bantuan alat produksi pertanian hingga alat pengolahan hasil pangan. Dari pemaparan di atas, dapat disimpulkan bahwa gerakan masyarakat Desa Solokuro berhasil. Hal ini karena antara cost (harga) yang harus dikeluarkan dan benefits (keuntungan) yang didapat jika diakumulasikan hasilnya akan lebih.

\section{DAFTAR PUSTAKA}

Fat'khah DH, Pamerdi GW \& Dewi KS (2015) Cyber-collective action netizen melalui media sosial Twitter Hastag \#SHAMEONYOUSBY. Jurnal Ilmu Komunikasi Fakultas Ilmu Sosial dan Komunikasi Universitas Kristen Satya Wacana.

Harrison L (2007) Metodologi Penelitian Politik. Jakarta: Kencana.

Lofland J (2003) Protes: Studi Tentang Perilaku Kolektif dan Gerakan Sosial. Yogyakarta: INSIST Press.

Mujiastuti T \& Hanif H (2015) Mandiri Tanpa Negara? Studi Tentang Kapasitas Komunitas Kinahrejo dalam Mendorong Aksi Kolektif untuk Mentransformasikan Kerentanan Menjadi Kekuatan Kemandirian Ekonomi Pascaerupsi Merapi di Penghujung Tahun 2010. Yogyakarta: Universitas Gajah Mada (Tesis). 
Olson M (2002) The Logic of Collective Action - Public Goods and The Theory of Group. Harvard University Press.

Rokhani (2018) Ekonomi Lokal, Berbasis Tindakan Kolektif dan Identitas dalam Menghadapi Pasar Ekspor Kopi (Studi Kasus di Nagori Buttu Saribu, Kecamatan Pamatang Sidamanik, Kabupaten Simalungun Sumatera Utara). Bogor: Institut Pertanian Bogor (Tesis).

Triwibowo D (2006) Gerakan Sosial: Wahana Civil Society bagi Demokratisasi. Jakarta: LP3ES. 